\title{
IMPLEMENTASI MODEL PEMBELAJARAN ARIAS (ASSURANCE, RELEVANCE, INTEREST, ASSESSMENT, SATISFACTION) UNTUK MENINGKATKAN AKTIVITAS DAN HASIL BELAJAR DALAM MATA KULIAH DASAR-DASAR AKUNTANSI PADA MAHASISWA PROGRAM S1 KKT JURUSAN PENDIDIKAN EKONOMI UNDIKSHA TAHUN 2012
}

\author{
Made Ary Meitriana ${ }^{1}$, Luh Indrayani ${ }^{2}$ \\ 1,2 Jurusan Pendidikan Ekonomi, Fakultas Ekonomi dan Bisnis \\ Universitas Pendidikan Ganesha \\ Singaraja, Indonesia
}

Email: ary.meitriana@yahoo.co.id ${ }^{1}$, luh.indrayani@yahoo.co.id ${ }^{2}$

\begin{abstract}
Abstrak
Penelitian ini bertujuan untuk 1) meningkatkan aktivitas belajar siswa, 2) meningkatkan hasil belajar siswa, dan 3) mengetahui respon siswa terhadap penerapan model pembelajaran ARIAS pada mahasiswa Program S1 KKT Jurusan Pendidikan Ekonomi tahun 2012 yang berjumlah 25 orang siswa. Penelitian ini merupakan penelitian tindakan kelas yang dilaksanakan dalam dua siklus. Hasil penelitian ini menunjukkan bahwa 1) penerapan model pembelajaran ARIAS dapat meningkatkan aktivitas belajar, 2) Penerapan model pembelajaran ARIAS dapat meningkatkan hasil belajar siswa, 3) Respon siswa terhadap penerapan model pembelajaran ARIAS berada pada kategori respon sangat positif

Kata kunci: model pembelajaran ARIAS, aktivitas belajar, hasil belajar, dan respon mahasiswa

Abstrac

This study aims to 1) improve student learning activities, 2) improving student learning outcomes, and 3) determine students' response to the application of the model on student learning ARIAS S1 KKT Program Department of Economic Education in 2012, amounting to 25 students. This research is a classroom action research was conducted in two cycles. Results of this study indicate that 1) the application of learning models can improve learning activity ARIAS, 2) Application of ARIAS learning model can improve student learning outcomes, 3) The response of students to the application of learning models in the category ARIAS very positive response
\end{abstract}

Keyword: ARIAS learning models, learning activities, learning outcomes, and student response 


\section{PENDAHULUAN}

Pendidikan merupakan salah satu kebutuhan pokok dalam kehidupan manusia yang berpikir bagaimana menjalani kehidupan dunia ini dalam rangka mempertahankan hidup. Untuk itu pemikiran dan realisasi ke arah upaya menghasilkan produk atau hasil pendidikan yang berkualitas harus terus dilakukan. Untuk memperoleh kualitas pendidikan yang baik, salah satu upayanya adalah meningkatkan kualitas proses belajar mengajar yang berlangsung dalam pendidikan. Proses belajar mengajar yang berlangsung dalam kelas akan berjalan baik jika guru dan siswa mempunyai cukup bekal. Bekal yang dimaksud adalah persiapanpersiapan dalam belajar mengajar. Persiapan tersebut mencakup persiapan mental baik dari guru maupun siswa, persiapan pengenalan terhadap tujuan pembelajaran, persiapan waktu belajar disesuaikan dengan tingkat perkembangan siswa.

Mata kuliah Dasar-Dasar Akuntansi merupakan salah satu mata kuliah yang diberikan kepada mahasiswa program S1 Kependidikan dengan Kewenangan Tambahan (S1 KKT). Mahasiswa yang mengikuti program S1 KKT pada Jurusan Pendidikan Ekonomi adalah mahasiswa dari Jurusan Pendidikan Geografi yang telah menyusun skripsi dan/ atau telah lulus S1 Kependidikan. Dengan diberikannya mata kuliah tambahan, diharapkan lulusan S1 Pendidikan geografi juga mampu mengajar mata pelajaran akuntansi baik di SMA ataupun SMK. Oleh karena itu, dalam waktu yang singkat Mahasiswa dalam program ini harus menguasai dan memahami setiap komponen dalam akuntansi hingga dihasilkannya suatu laporan akuntansi baik dalam perusahaan jasa maupun perusahaan dagang. Menyadari hal tersebut, penting bagi penulis untuk menerapkan model pembelajaran yang tepat dalam pelaksanaan mata kuliah Dasar-Dasar Akuntansi. Penggunaan model pembelajaran yang tepat selain dapat mengarahkan kegiatan belajar terhadap tata cara pembelajaran, juga mampu merangsang mahasiswa untuk belajar, mempunyai minat yang besar terhadap perkuliahan, sehingga mahasiswa pada akhirnya mampu menghasilkan aktivitas dan hasil belajar mereka secara optimal.

Model pembelajaran ARIAS terdiri dari lima komponen (assurance, relevance, interest, assessment, dan satisfaction). Kelima komponen tersebut merupakan satu kesatuan yang diperlukan dalam kegiatan pembelajaran. Komponen pertama model pembelajaran ARIAS adalah assurance (percaya diri), yaitu berhubungan dengan sikap percaya, yakin akan berhasil atau yang berhubungan dengan harapan untuk berhasil. Sikap 
percaya diri, yakin akan berhasil ini perlu ditanamkan kepada mahasiswa untuk mendorong mereka agar berusaha dengan maksimal guna mencapai keberhasilan yang optimal. Dengan sikap yakin, penuh percaya diri dan merasa mampu dapat melakukan sesuatu dengan berhasil, mahasiswa terdorong untuk melakukan sesuatu kegiatan dengan sebaik-baiknya sehingga dapat mencapai hasil yang lebih baik dari sebelumnya atau dapat melebihi orang lain.

Komponen kedua model pembelajaran ARIAS, relevance, yaitu hubungan atau kaitan. Maksudnya kegiatan pembelajaran harus berhubungan dengan kehidupan mahasiswa baik berupa pengalaman sekarang atau yang telah dimiliki maupun yang berhubungan dengan kebutuhan karir sekarang atau yang akan datang. Mahasiswa merasa kegiatan pembelajaran yang mereka ikuti memiliki nilai, bermanfaat dan berguna bagi kehidupan mereka. Mahasiswa akan terdorong mempelajari sesuatu kalau apa yang akan dipelajari ada relevansinya dengan kehidupan mereka, dan memiliki tujuan yang jelas. Sesuatu yang memiliki arah tujuan, dan sasaran yang jelas serta ada manfaat dan relevan dengan kehidupan akan mendorong individu untuk mencapai tujuan tersebut.

Komponen ketiga model pembelajaran ARIAS, interest, yaitu yang berkaitan dengan perhatian atau minat mahasiswa. Minat merupakan salah satu aspek psikis manusia yang dapat mendorongnya untuk mencapai tujuan yang ingin dicapai. Dengan demikian penting bagi guru untuk tidak hanya sekedar menarik minta/perhatian mahasiswa pada awal kegiatan pembelajaran melainkan tetap memelihara minat/perhatian tersebut selama kegiatan pembelajaran berlangsung. Sehingga dengan minat yang besar pada pelajaran yang sedang diajarkan mahasiswa akan mampu meningkatkan hasil belajar mereka.

Komponen keempat model pembelajaran ARIAS, assessment, yaitu yang berhubungan dengan penilaian. Penilaian merupakan suatu bagian pokok dalam pembelajaran yang memberikan keuntungan bagi dosen dan mahasiswa. Penilaian dilaksanakan untuk mengetahui sampai sejauh mana kemajuan yang dicapai atau hasil belajar yang diperoleh mahasiswa.

Komponen kelima model pembelajaran ARIAS, satisfaction, yaitu yang berkaitan dengan penguatan yang diberikan pada mahasiswa. Penguatan ini penting dalam pembelajaran untuk mengokohkan perilaku positif mahasiswa. Sehingga saat sebuah perilaku positif mengalami penguatan maka tingkah laku tersebut akan cenderung untuk muncul kembali pada masa mendatang, dengan demikian peningkatan hasil belajar dapat 
dicapai. Pemahaman dan kemampuan mahasiswa dalam menguasai materi perkuliahan dapat dilihat dari kualitas pembelajaran (aktivitas dan hasil belajar mahasiswa). Model pembelajaran yang memberi peluang paling tinggi terjadinya kualitas pembelajaran secara optimal adalah model pembelajaran ARIAS.

Penelitian ini termasuk jenis penelitian tindakan kelas (classroom action research), hal ini dipilih atas dasar masalah dan tujuan penelitian yang memerlukan berbagai informasi dan tindak lanjut yang terjadi di lapangan. Melalui implementasi model pembelajaran ARIAS diharapkan dapat meningkatkan aktivitas dan hasil belajar serta mengetahui respon mahasiwa terhadap implementasi model ARIAS pada pembelajaran Dasar-Dasar Akuntansi agar mahasiswa dapat memahami dan menguasai materi secara optimal.

\section{METODE}

\section{Adapun}

penelitian yang dipilih atau digunakan dalam penelitian tindakan kelas ini adalah terdiri dari beberapa tahapan yang akan dilakukan diantaranya: perencanaan tindakan, Pelaksanaan tindakan, Observasi dan Evaluasi, dan Refleksi. Dalam pelaksanaan tahapan-tahapan tersebut merupakan suatu siklus yaitu tindakan terus-menerus dilaksanakan untuk mencapai tujuan dalam meningkatkan aktivitas dan hasil belajar mahasiswa.

Konsep dasar langkah-
langkah penelitian dikembangkan dalam penelitian ini dapat dilihat pada gambar 1 .

Penelitian ini dilaksanakan

di Program S1 KKT Jurusan Pendidikan Ekonomi Undiksha. Subjek penelitian ini adalah mahasiswa Program S1 KKT Jurusan Pendidikan Ekonomi tahun 2012 yang berjumlah 25 orang. Sedangkan objek penelitiannya adalah aktivitas belajar mahasiswa serta hasil belajar mahasiswa terhadap pembelajaran Dasar-Dasar Akuntansi melalui Implementasi model pembelajaran ARIAS. Instrumen dan teknik pengumpulan data disesuaikan dengan jenis data yang diperlukan seperti disajikan pada tabel 1 . 
Tabel 1. instrument Penilaian dan Teknik Pengumpulan Data

\begin{tabular}{|l|l|l|l|}
\hline No & Jenis Data & $\begin{array}{l}\text { Teknik } \\
\text { Pengumpulan } \\
\text { Data }\end{array}$ & Instrumen Penilaian \\
\hline 1 & $\begin{array}{l}\text { Aktivitas atau perilaku } \\
\text { mahasiswa dalam } \\
\text { pembelajaran }\end{array}$ & Observasi & $\begin{array}{l}\text { Pedoman } \\
\text { Observasi }\end{array}$ \\
\hline 2 & Hasil Belajar mahasiwa & $\begin{array}{l}\text { Tes, Tugas, dan } \\
\text { autentik asesmen }\end{array}$ & $\begin{array}{l}\text { Tes hasil belajar, } \\
\text { tugas, dan autentik } \\
\text { asesmen }\end{array}$ \\
\hline 3 & $\begin{array}{l}\text { Kendala-kendala } \\
\text { implementasi model } \\
\text { pembelajaran }\end{array}$ & Observasi & $\begin{array}{l}\text { Jurnal/ catatan } \\
\text { harian peneliti }\end{array}$ \\
\hline 4 & Respon mahasiswa & kueisioner & Angket \\
\hline
\end{tabular}

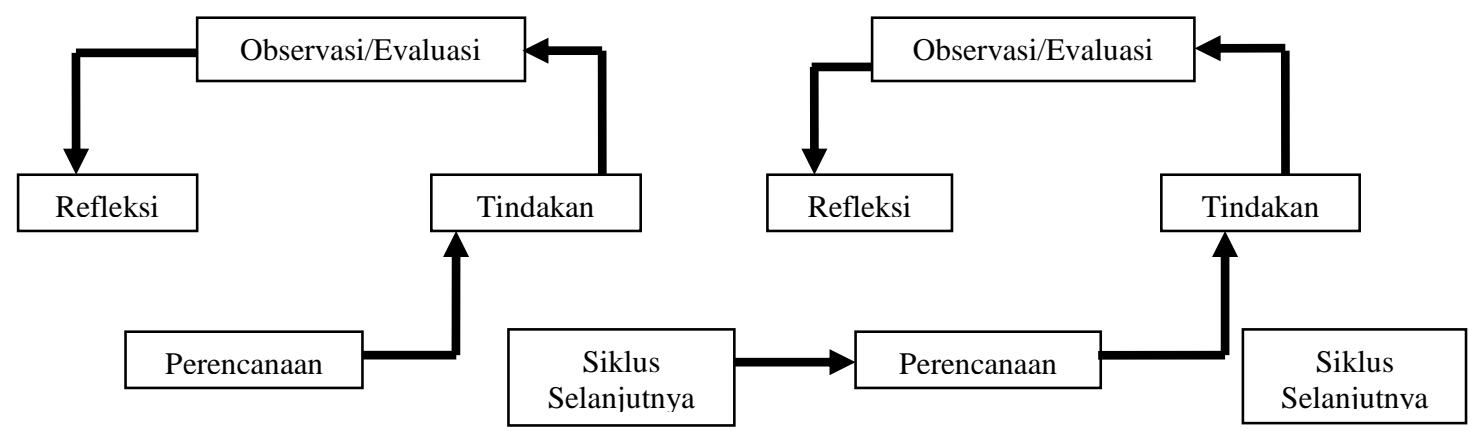

Gambar 1. Alur tindakan pada siklus peneliti

(dimodifikasi dari Kemmis dan Mc.Taggrat)

Penelitian ini dilaksanakan dalam 2 siklus. Data yang diperoleh pada masing-masing siklus dianalisis secara deskriptif-interpretatif. Sebagai ukuran keberhasilan digunakan patokan di bawah ini.

1. Aktivitas mahasiswa dalam pembelajaran berada pada katagori baik.Perkuliahan dianggap berhasil jika $\geq 85 \%$ mahasiswa lulus dengan nilai $A$ atau $\mathrm{B}$.

2. Respon mahasiswa terhadap penyelenggaraan pembelajaran positif.

Penilaian menggunakan pedoman konservasi PAP seperti tercantum dalam Buku Pedoman Studi Universitas Pendidikan Ganesha tahun 2010. 
Tabel 2. Pedoman Konversi Nilai

\begin{tabular}{|c|c|c|c|}
\hline \multirow{2}{*}{} & \multicolumn{3}{|c|}{ Nilai } \\
\cline { 2 - 4 } & Angka & Huruf & Predikat/ Katagori \\
\hline $85-100$ & 4 & A & Sangat Baik \\
\hline $70-84$ & 3 & B & Baik \\
\hline $55-69$ & 2 & C & Cukup \\
\hline $46-54$ & 1 & D & Kurang \\
\hline $0-45$ & 0 & E & Sangat Kurang \\
\hline
\end{tabular}

\section{HASIL DAN PEMBAHASAN}

Penelitian dilaksanakan selama dua siklus menunjukkan terjadinya peningkatan aktivitas dan hasil belajar mahasiswa melalui penerapan model pembelajaran ARIAS. Pada pertemuan pertama rata-rata aktivitas belajar mahasiswa sebesar 12,64\% dan pada pertemuan kedua mengalami peningkatan sebesar 1,12 \% menjadi $13,76 \%$, sehingga jika dicari nilai rata-rata aktivitas belajar mahasiswa pada siklus I sebesar $13,20 \%$ berada pada ketegori kurang aktif. Pada siklus II pertemuan pertama rata-rata nilai aktivitas belajar mahasiswa sebesar $17,16 \%$ dan pada pertemuan kedua mengalami peningkatan menjadi $17,88 \%$, sehingga jika dicari rata-rata aktivitas belajar mahasiswa pada siklus II sebesar $17,52 \%$ pada kategori Aktif.

Siklus I dan II aktivitas belajar mahasiswa mengalami peningkatan namun pada proses pembelajaran siklus I masih terdapat kendala dan kelemahan dalam proses pembelajaran. Kendala dan kelemahan tersebut kemudian ditindaklanjuti untuk mencari alternatif pemecahan dalam melaksanakan siklus yang ke II. Pada siklus II aktivitas belajar mahasiswa sudah mengalami peningkatan dan sudah mengarah kepada pembelajaran ARIAS, dimana mahasiswa sudah memperlihatkan aktivitasnya dengan berani mengeluarkan pendapatnya, percaya diri tampil didepan kelas untuk mempersentasikan hasil diskusinya, pemberian penghargaan (reward) mampu meningkatkan aktivitas belajar mahasiswa hal ini dikarenakan dengan pemberian reward membuat mahasiswa lebih bersemangat untuk belajar, semua mahasiswa bekerjasama pada saat diskusi kelompok sehingga alokasi waktu pelaksanaan diskusi dapat berjalan secara lancar, sebagian besar mahasiswa sudah termotivasi untuk bertanya dan memberikan pendapat kepada 
kelompok lain saat persentasi dan aktivitas belajar mahasiswa lebih aktif dan menarik karena selama proses pembelajaran minat mahasiswa untuk belajar tetap terjaga dengan model pembelajaran ARIAS. Model pembelajaran ARIAS merupakan model pembelajaran yang fleksibel yang bisa dilakukan baik dengan cara berkelompok maupun tidak berkelompok. Namun penelitian yang dilakukan oleh peneliti adalah penelitian dengan cara menerapkan teknik berkelompok. Keberhasilan dalam proses pembelajaran dapat dilihat dari hasil belajar yang dicapai oleh setiap mahasiswa. Hal ini tergantung kepada bagaimana cara seorang pendidik untuk merubah pengetahuan mahasiswa dalam artian perubahan pengetahuan, sikap dan perilaku mahasiswa setelah menyelesaikan pengalaman belajarnya, kualitas dan kuantitas penguasaan tujuan intruksional harus dicapai, hasil belajar yang memuaskan, pemahaman teori yang tahan lama dan dapat digunakan sebagai dasar dalam mempelajari bahan berikutnya. Model pembelajaran ARIAS dapat dijadikan strategi untuk memperbaiki proses belajar mengajar sehingga dapat mencapai tujuan yang diinginkan. Model pembelajaran ARIAS dapat meningkatkan hasil perkuliahan Akuntansi karena model pembelajaran ARIAS berusaha untuk menumbuhkan percaya diri mahasiswa untuk belajar, menjaga minat mahasiswa selama proses pembelajaran berlangsung, mengajarkan mahasiswa pelajaran yang sesuai dengan kenyataan yang mereka hadapi/sesuai dengan yang ada dilingkungannya sehingga mahasiswa tertarik untuk belajar karena dirasa akan bermanfaat bagi dirinya, pemberian penghargaan (reward) menjadi suatu rangsangan yang dapat meningkatkan semangat belajar mahasiswa. Kegiatan pembelajaran yang dilakukan dengan berkelompok ini akan membuat mahasiswa dapat bertukar pikiran dengan kelompoknya, belajar bekerjasama dan akan timbul persaingan positif yang akan berimbas pada bagaimana cara mahasiswa untuk mendapatkan hasil yang terbaik, baik didalam kelompok maupun dengan teman sekelasnya.

Peningkatan hasil belajar dicapai melalui variasi kegiatankegiatan pembelajaran seperti dosen memberikan soal-soal transaksi yang sering terjadi dalam perusahaan, sehingga mahasiswa termotivasi untuk belajar, mengaitkan materi dengan kenyataan yang sedang mahasiswa hadapai atau yang berada dalam lingkungan sekitarnya, dan memberikan penghargaan sebagai timbal balik dari kegiatan mahasiswa serta hasil yang dicapai mahasiswa akan membuat mahasiswa lebih bersemangat untuk belajar. 
Berdasarkan hal tersebut, dapat dilihat bahwa penerapan model pembelajaran ARIAS dapat meningkatkan hasil belajar mahasiswa program S1 KKT Jurusan Pendidikan Ekonomi Undiksha tahun 2012.

Pada akhir siklus II peneliti menyebarkan kuisioner respon mahasiswa terhadap penerapan model pembelajaran ARIAS didalam proses belajar dikelas. Dari penyebaran kuisioner yang disebarkan kepada 25 mahasiswa diperoleh data tentang respon mahasiswa terhadap penerapan model pembelajaran ARIAS. Ratarata respon mahasiswa sebesar $42,88 \%$ tergolong sangat positif. Hal ini mengindikasikan bahwa mahasiswa senang dengan model pembelajaran ARIAS yang diterapkan dikelas saat perkuliahan berlangsung.

\section{SIMPULAN DAN SARAN}

Berdasarkan hasil dan pembahasan yang telah dilakukan, dapat disimpulkan bahwa penerapan model pembelajaran ARIAS dapat meningkatkan aktivitas belajar mahasiswa. Penerapan model pembelajaran ARIAS dapat meningkatkan hasil belajar. Respon mahasiswa sangat positif terhadap penerapan model pembelajaran ARIAS.

Berdasarkan simpulan yang dipaparkan di atas dapat diungkapkan saran terkait dengan hasil penelitian ini adalah sebagai berikut. Diharapkan kepada peneliti selanjutnya melakukan penelitian lebih lanjut pada penerapan model pembelajaran ARIAS pada pokok bahasan yang berbeda untuk mengetahui efektifitas penerapan model pembelajaran ini dan agar memperhatikan kendala-kendala yang dihadapi peneliti sebagai bahan pertimbangan untuk perbaikan dan penyempurnaan pelaksanaan penelitian berikutnya.

\section{DAFTAR PUSTAKA}

Agung, A.A. Gede. 2010. Evaluasi pendidikan.

Singaraja:Undiksha.

Arikunto, Suharsimi. 2009. Prosedur penelitian. Jakarta:Rineka Cipta.

Defri Ahmad Chaniago. 2012. Ciri-ciri aktivitas belajar. Tersedia pada http://id.shvoong.com/socia 1-sciences/1961162-

aktifitas-belajar/.(diakses tanggal 24 Januari 2012).

Dimyati dan Mudjiono, 2002. Belajar dan pembelajaran. Jakarta:Rineka Cipta.

-------, 2006. Belajar dan Pembelajaran. Jakarta :Rineka Cipta.

Ihsan, Fuad. 2006. Belajar dan Pembelajaran. Jakarta: Rineka Cipta.

Kusumayanti, Emi Luh. 2011. Penerapan Model Pembelajaran DiscoveryInkuiri untuk Meningkatkan Aktivitas Dan Prestasi 
Belajar Siswa Kelas IV Pada Pembelajaran Sains SD No. 5 Penarukan Tahun Pelajaran 2011/2012. Jurusan Pendidikan Sekolah Dasar, FIP. Undiksha: Singaraja.

Kusumah, Wijaya. 2008. Minat Belajar. Tersedia pada http://edukasi.kompasiana .com/2009/12/16/apakahminat-itu/.(diakses tanggal 9 Maret 2012).

Nurkancana, Wayan dan Sunartana. 1992. Evaluasi Hasil Belajar. Surabaya: Usaha Nasional.

Prasetyaningsih, Astuti. 2010

Minat Belajar. Tersedia pada

http://edukasi.kompasiana.c om/2010/10/02/minatbelajar/.(diakses tanggal 9 Maret 2012).

Ruslan. 2010. Hubungan Minat Baca Dan Lingkungan Keluarga Dengan Kemampuan Memahami Dan Menggunakan Unsur Serapan Bahasa Asing Siswa Kelas III MA Nw Pancor Selong Lombok Timur. Tesis (tidak diterbitkan).Singaraja:

Program Pasca Sarjana Undiksha Singaraja.

Sardiman. 2005, Interaksi Motivasi Belajar Mengajar.
Jakarta:PT

Grasindo

Persada.

Sugiyono.2010. Metode Penelitian Kuantitatif Kualitatif Dan $R \& D$. Bandung: Alfabeta.

Sudjana, Nana, 2004. Penilaian Hasil Proses Belajar Mengajar. Bandung: Remaja Rosdakarya Offset. ------, 2010. Penilain Hasil Proses Belajar Mengajar. Bandung. PT Remaja Rosdakarya Offset.

Suherman, Eman. 2008. Desain Pembelajaran

Kewirausahaan. Bandung: Alfabeta.

Suryabrata, Sumadi, 1983. Psikologi

Pendidikan.Yogyakarta:

Erlangga.

Suryana. 2003. Kewirausahaan. Jakarta: Salemba Empat.

Werti. 2010. Impementasi pembejaran tematik berbantuan cerita dalam meningkatkan aktivitas prestasi belajar calistung peserta didik kelas III SDN 1 semara pura tengah. Tesis (tidak diterbitkan). Singaraja. Program Pascasarjana Undiksha Singaraja.

Widihadmoko, Suroso. 2010. Model - Model Pembelajaran Efektip. Tersedia pada 
http//:4shared.com tanggal

24 Januari 2012). 